УДК $616.314 .2-002.2$

DOI

(C). В. Гасюк

ДВНЗ «Тернопільський державний медичний університет імені I. Я. Горбачевського»

\title{
Характеристика клітинного складу червоної облямівки при атопічному хейліті
}

Резюме. У статті приведено результати цитологічного дослідження клітинного складу червоної облямівки у хворих на атопічний хейліт. Отримані результати дадуть можливість динамічно спостерігати за даним контингентом осіб за умови призначення комплексного етіотропного, патогенетичного, симптоматичного лікування даної нозологічної одиниці.

Ключові слова: хейліт, червона облямівка, клітини, ядро, мікрофлора.

\section{Н. В. Гасюк}

ГВУЗ «Тернопольский госсударственный медицинский университет имени И. Я. Горбачевского»

\section{Характеристика клеточного состава красной каймы при атопическом хейлите}

Резюме. В статье приведены результаты цитологического исследования клеточного состава красной каймы губ при атопическом хейлите. Полученные результаты дают возможность динамически наблюдать за данным контингентом лиц при условии назначения комплексного этиотропного, патогенетического, симптоматического лечения данной нозологической единицы.

Ключевые слова: хейлит, красная кайма, клетки, ядро, микрофлора.

\section{N. V. Hasyuk}

I. Horbachevsky Ternopil State Medical University

\section{Characteristics of cell composition of red border in the case of atopic cheilitis}

Summary. The article presents results of cytological examination of cell composition of red border in patients with atopic cheilitis. Obtained results will make it possible to provide dynamic observation of this contingent of persons during indication of complex, etiological, pathogenetic, symptomatic treatment of this nosological unit.

Key words: cheilitis, red border, cell composition, nucleus, microflora.

Вступ. В умовах філогенетичної та анатомічної єдності шкіри та червоної облямівки, впливу зовнішнього середовища, малюнок дрібних дерматогліфічних борозен шкіри і червоної облямівки втрачає своє регіонарне відмежування, що робить дану ділянку сприятливою до вПливу екзогенних чинників та розвитку патологічних процесів. Особливе місце серед останніх посідає атопічний хейліт, який може развиватися як самостійне захворювання, так і бути симптом атопічного дерматиту [9].

Сучасні уявлення про етіологію та патогенетичні механізми розвитку атопічного хейліту є мультифакторними, що зумов- 
лено обтяженою полігенною спадковістю до атопії. Вказана нозологія є своєрідним локальним проявом атопічного дерматиту або нейродерміту [10].

Значну роль у розвитку атопічного хейліту відіграють інфекційні агенти, емоційне напруження, зміни взаємодії холінергічної і симпатоадреналової систем, стабільність цитоплазматичних мембран, зумов лена станом вільнорадикального окиснення ліпідів, активація метаболізму арахідонової кислоти з підвищенням синтезу лейкотрієнів та простагландинів [11].

Також факторами ризику розвитку атопічного хейліту є полівалентна алергія, захворювання нервової та ендокринної систем на тлі сприятливої спадковості (рис. 1).

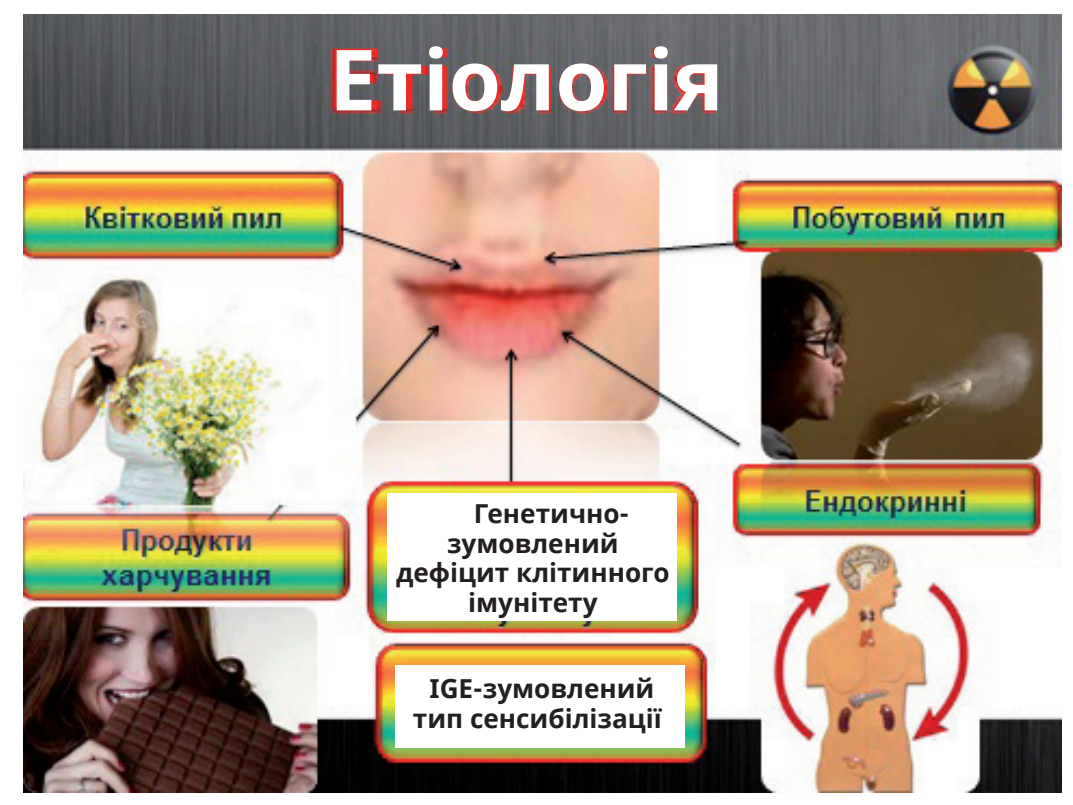

Puc. 1. Схема факторів ініціації атопічного хейліту.

Літературні дані останніх років вказують на роль генетичних чинників у розвитку первинної та вторинної стоматологічної патології $[4,5]$.

Не виключено, що гени, які кодують схильність до атопії, локалізуються в сегменті q22 хромосоми 21 [2, 3, 7].

Генетичні чинники визначають початкові порушення бар'єрної функції епідермісу, що спричиняє високу його проникливість для подразнювальних речовин та атопенів [12].

Метою дослідження стало визначення особливостей клітинної червоної облямівки губ у хворих на атопічний хейліт.

Матеріали і методи. Матеріалом для дослідження слугував клітинний склад, отриманий шляхом зскрібання, забраний в ділянці кутів рота у 16 осіб молодого віку (24-31 рік), хворих на атопічний хейліт відповідно у гострій (7 осіб) та хронічній (9 осіб) фазах. Матеріал забирали шпателем, із подальшим перенесенням на предметне скло та висушуванням при відкритому доступі повітря протягом 3-5 хвилин. Забарвлення матеріалу проводили за Романовським-Гімзою 3 подальшим мікроскопічним та морфологічним аналізом з урахуванням відсоткового співвідношення різних форм епітеліоцитів у нормі.

Кожна анатомічна ділянка слизової оболонки порожнини рота має свій зональний тип зроговіння і на гістологічних зрізах характеризується наявністю базального, шипуватого, зернистого та рогового шарів, при яких зроговіння відбувається як за рахунок ортокератозу поетапного процесу, так i апоптичних змін у поверхневому шарі епітелію $[1,6]$.

Дещо по-іншому відбувається процес зроговіння власне червоної облямівки, що знижує її бар’єрну функцію та робить органом-мішенню на етапі виникнення та розвитку патології вказаної анатомічної локалізації. 3 метою уніфікації шарів 
епітелію та більш глибшого вивчення, у дослідженнях ми користуємося цитологічною класифікацією, згідно з якою в епітелії виділено базальні, парабазальні, проміжні, поверхневі клітини та рогові лусочки [8].

Результати досліджень та їх обговорення. В осіб обстеженого контингенту атопічний хейліт характеризувався тривалим перебігом, із періодами загострення та ремісії, при чому слід відзначити, що 11 пацієнтів (68,75 \%) основним провокуючим чинником відмічали стресовий. 5 осіб (31,25 \%) загострення нозології пов'язували із сезонністю (активація процесу взимку та осінню, і ремісія влітку).

Основними скаргами пацієнтів у фазі загострення були печіння, почервоніння та лущення червоної облямівки губ. Печіння є одним із перших симптомів у $13(81,25 \%)$ і в подальшому супроводжується набряком та інфільтрацією червоної облямівки. 3 особи (18,75 \%) у якості перших симптомів вказували на лущення. Причому топографія ураження поширюється на кути рота. 4 особи (25 \%) скаржились на больові відчуття при відкритті рота, які ініційовані тріщинами внаслідок інфільтрації і сухості шкіри та червоної облямівки.

Скарги пацієнтів у фазі ремісії були на лущення та потовщення шкіри в ділянці вогнища ураження. Суб’єктивні відчуття у вигляді печіння, провокативного характеру відмічали 2 пацієнти (12,5 \%). 16 осіб (100 \%) вказували на лущення шкіри різної інтенсивності із переважним ураження шкіри кутів рота та посилення шкірного малюнка даної анатомічної ділянки.

Ураження шкіри були наявні у 12 осіб (75 \%). Слід зауважити, що прояви на шкіpi характеризувались як типовою локалізацією 8 осіб (ліктьові й підколінні згини), так і атиповою, 4 особи (25 \%) (над верхніми повіками, завушною ділянкою, в ділянці гомілково-плеснових суглобів).

Згідно $з$ даними анамнезу, в (11) із (16) пацієнтів патологічний процес $є$ наслідком гострого процесу шкіри в дитячому віці 3 подальшою хронізацією, разом 3 тим, як 5 осіб відмічали виникнення захворювання у віці 17-20 років.
Таким чином, детальний аналіз анамнестичних даних дозволив установити що атопічний хейліт у осіб обстеженого контингенту може розвиватися на тлі типових клінічних проявів атопічного дерматиту або як ізольоване хронічне ураження червоної облямівки та шкіри навколо неї унаслідок гострої фази атопічного дерматиту.

При об'єктивному обстеженні пацієнтів у фазі загострення визначалася відсутність чіткої регіонарності між шкірою та червоною облямівкою, що вказує на генералізацію процесу із переходом на шкірну частину та власне червону облямівку. Місце ураження характеризувалося наявністю тріщин різної глибини на тлі лущення переважно великолусочкового характеру. Лусочки мали тенденцію до нашарувань на тлі еритематозних змін, сухості та лехенізації.

Місцеві зміни при атопічному хейліті в стадії ремісії проявлялися лущенням переважно дрібнолусочкового характеру в ділянці кутів рота на тлі сухості та еритеми, були наявні лусочки ексфоліативного характеру в ділянці змикання губ.

Основним компонентом клітинного складу червоної облямівки є клітини багатошарового плоского епітелію. Вони наявні в цитограмах як у нормі, так і патології. Слід зазначити, що клітини плоского епітелію неоднорідні, що відображає гетерогенність клітин епітеліального покриву вказаної анатомічної локалізації [6]. При атопічному хейліті цитологічний клітинний склад змінюється як в епітеліальній, так і сполучнотканинній складовій.

При цьому відображаючи перебіг атопічного хейліту (гостра фаза чи фаза ремісії) та інтенсивність запальнодеструктивних процесів у тканинах, клітинний склад цитограм ми поділили на два цитоспецифічних типи.

У клітинному складі цитограм фази загострення переважають над клітинами проміжного шару, цитологічна організація яких відповідає класовій належності та рівню диференціації, у великій кількості візуалізується патогенна мікрофлора та клітини запальної реакції. Візуалізуються також поверхневі епітеліоцити. Потужний мікроб- 
ний склад ініціює в подальшому некробіотичні процеси як в епітеліоцитах, так і у сегментоядерних лейкоцитах. Паралельно до цього, за рахунок фагоцитозу відбувається руйнація цитоплазми сегментоядерних лейкоцитів. Кокова мікрофлора адгезує не лише на поверхні епітеліальних клітин, а й на поверхні сегментоядерних лейкоцитів. Окрім того, поряд із гематогенними клітинами в цитограмах візуалізується переважно кокова флора та поодинокі нитки псевдоміцелію грибів роду Candida (рис. 2).

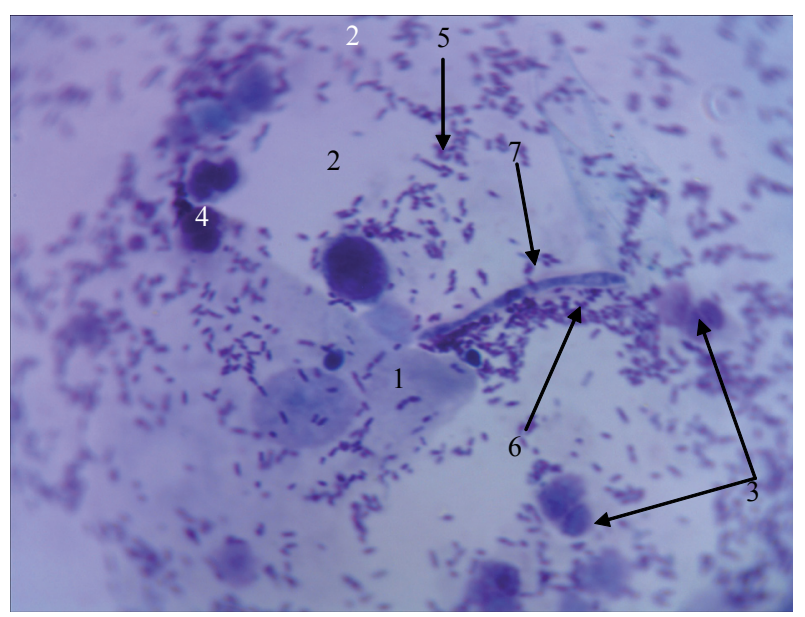

Puc. 2. Клітинний склад червоної облямівки при атопічному хейліті в фазі загострення. Забарвлення за Романовським-Гімзою. ×400: 1 - проміжний епітеліоцит; 2 - поверхневий епітеліоцит; 3 - лімфоцитарна інфільтрація; 4 - сегментоядерні лейкоцити у вогнищі запалення; 5 - паличкова флора; 6 - кокова флора;

7 - псевдоміцелій грибів роду Candida.

Отримані результати комплексного цитологічного та мікробіологічного аналізу узгоджуються із напрацюваннями попередників стосовно порушення мікробіологічної та імунологічної ланок колонізаційної резистентності та дизбіотичних змін червоної облямівки губ і проявляються надмірним обсіменінням St. aureus, St. epidermidis, St. pyogenes, Enterococus faecium i грибами роду Candida. Кількісні показники обсіменіння зростають зі збільшенням ступеня тяжкості та поширеності уражень, обтяженості анамнезу загальносоматичною патологією [11].

Привертає увагу наявність лімфоцитів, які мають невеликі розміри, оптично щільне ядро, по периферії якого візуалізується світлий обідок слабобазофільної ци- топлазми, що підтверджує напрацювання A. Nassif, A. Bensussan [12] стосовно ролі сенсебілозованих лімфоцитів у розвитку даної патології.

Проміжні клітини мають азурпозитивну цитоплазму та центрично розташоване ядро. У частини клітин цитоплазма видовжена та узурована. Клітини розташовані переважно скупченнями. Визначається зміна мікробного складу, який у даного типу цитограм представлений переважно коками, які адгезують на поверхні епітеліальних клітин. Клітинний склад відображає посилення фагоцитарної реакції сегментоядерних лейкоцитів, i як наслідок, незавершеного фагоцитозу, в процесі фагоцитозу лейкоцити зазнають специфічних змін у вигляді зміни перебудови ядерного апарату, разом 3 тим, як в епітеліоцитах відбуваються некробіотичні процеси спочатку в цитоплазмі, а потім в ядрі. При цьому відмічається збільшення в об'ємі епітеліоцитів, цитоплазма їх заповнена вакуолями, які містять прозору рідину. Ядро переміщується на периферію клітини, іноді в ньому з'являються вакуолі або ядро зморщується. В подальшому відбувається розпад ультраструктурних елементів клітини і вона переповнюється водою.

Аналізуючи клітинний склад цитограм, можемо дійти наступного висновку, що за умов загостреного перебігу атопічного хейліту, епітеліоцити підлягають більшому ступеню деструкції, що супроводжується каріопікнозом і каріорексисом ядра та гомогенізацією цитоплазми. Рогові лусочки у цитограмах зустрічаються в значно меншій кількості порівняно із ï клітинним складом цитограм осіб із хронічним перебігом. Вони здебільшого еозинофільні, полігональної форми, характеризуються відсутністю чіткості контурів та узурацією. Розміщення даних елементів диферону епітеліальної клітини розрізнене.

Клітинний склад цитограм у фазі ремісії характеризується наявністю в клітинному складі одиничних представників паличкової флори, поверхневих та проміжних епітеліоцитів. Поверхневі епітеліоцити мають кубічну та прямокутну 
або полігональну форму, в цитоплазмі містяться поодинокі азурпозитивні гранули. Ядро округле, іноді овальне. Слід відмітити наявність тенденції до скупченого розташування клітин даного класу. В цитограмах вказаний клас клітин має ознаки подразнення у вигляді гомогенізації та вакуолізації цитоплазми, як прояв тривалого подразнення клітини бактеріальною агресією, що проявляється різкою базофілією. При цьому проміжні клітини зустрічаються в нормі й здебільшого без елементів цитопатології. Слід відзначити наявність великої кількості рогових лусочок (рис. 3).

Висновки. Характер змін клітинного складу червоної облямівки зумовлений клінічним перебігом атопічного хейліту. Проведений комплексний аналіз цитограм дає можливість розглянути атопічний хейліт в осіб обстеженого контингенту за умов відсутності адекватної терапії, як безперервний самовільний процес. Його складові (запальноінфільтративна і деструктивна) можуть регресувати під впливом ефективного лікування і знову активуватися при загостренні процесу

\section{Список літератури}

1. Быков В. Л. Функциональная морфология эпителиального барьера слизистой оболочки полости рта / В. Л. Быков // Стоматология. - 1997. № 3. - С. 12-17.

2. Баранов В. С. Генетический паспорт - основа индивидуальной и предикативной медицины / Баранов В. С. - «Н-Л», 2009. - 528 с.

3. Баранов В. С. Цитогенетика эмбрионального развития человека / В. С. Баранов, Т. В. Кузнецова. - «Н-Л», 2007. - 658 с.

4. Гасюк Н. В. Роль поліморфізму ядерного фактора транскрипції NF-кB1 у патогенезі генералізованого пародонтиту / Н. В. Гасюк // Світ медицини і біології. - 2015. - № 3. - С. 28-31.

5. Гасюк Н. В. Характеристика поліморфних варіантів ядерного фактора транскрипції NF-кB1 як предикторів розвитку генералізованого пародонтиту / Н. В. Гасюк, Г. А. Єрошенко // Галицький лікарський вісник. - 2015. - № 3 (ч. 1). -С. 13-16.

6. Гасюк Н. В. Цитологічні і цитогенетичні особливості слизової оболонки порожнини рота в нормі та при запальному процесі : автореф. дис. на здобуття наук. ступеня д. мед. наук : спец. 14.03.09 «Гістологія, цитологія, ембріологія» / Н. В. Гасюк. - Київ, 2016. - 40 с.

7. Вишня О. Г. Кожная патология у детей из синдромом Дауна : автореф. дисс. на соискание

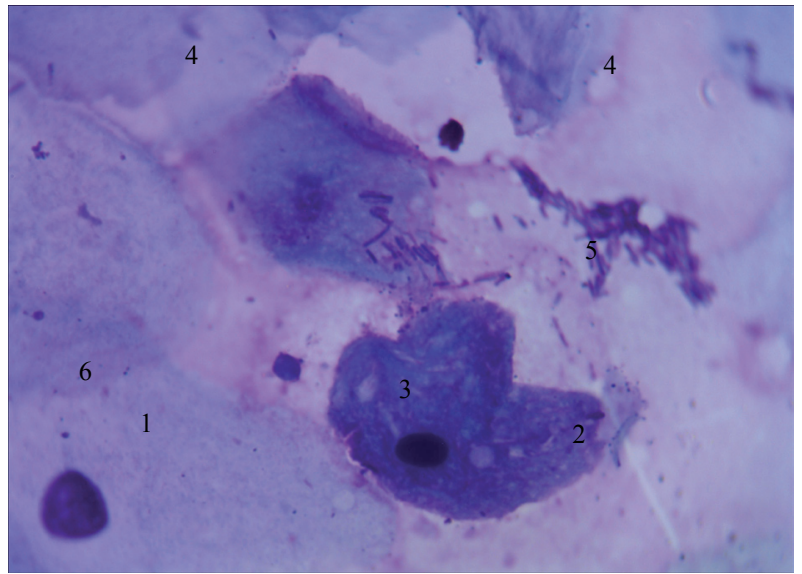

Puc. 3. Клітинний склад червоної облямівки при атопічному хейліті в фазі ремісіі.

Забарвлення за Романовським-Гімзою. ×400: 1 - проміжний епітеліоцит; 2 - поверхневий епітеліоцит; 3 - базофільна цитоплазма;

4 - рогові лусочки; 5 - паличкова флора; 6 поодинокі азурпозитивні гранули.

під впливом провокуючих чинників, а саме нейрогенного та сенсебілізаційного. Отримані дані вказують на патогенетичну значимість деструктивних змін епітеліоцитів та порушення колонізаційної резистентності на клінічний перебіг атопічного хейліту.

ученой степени канд. мед. наук : спец. 14.00.11 «Кожные и венерические болезни» // О. Г. Вишня. Москва, 2003. - 23 с.

8. Ланге Д. Е. Диагностика, клиника и лечение язвенных, везикулобуллезных и десквамативных поражений полости рта / Д. Е. Ланге // Клиническая стоматология. - 1999. - Т. 1, № 4. - С. 44-47. 9. Савичук Н. О. Основные клинические проявления атопического хейлита у детей и подростков / Н. О. Савичук, М. М. Соломонюк // Современная стоматология. - 2003. - № 1. - С. 70-72.

10. Соломонюк М. М. Особливості клініки та фактори ризику виникнення атопічного хейліту / М. М. Соломонюк // Ліки України. - 2004. - № 1. C. $79-81$.

11. Соломонюк М. М. Обгрунтування вибору методу терапії атопічного хейліту у дітей та підлітків : автореф. дис. на здобуття наук. ступеня канд. мед. наук : спец. 14.01.22 «Стоматологія» / М. М. Соломонюк. - Київ, 2006. - 20 с.

12. Nassif A. Toxic epidermal necrolysis effektor cells are drug-specific cytotoxic T cels / A. Nassif, A. Bensussan // J. Allergi Clin. Imunnol. - 2004. № 114 (5) - P. 1209-1215. 